\title{
Effect of modified cassava starch on the rheological and quality properties of a dairy beverage prepared with sweet whey
}

\author{
Paola Catalina IMBACHÍ-NARVÁEZ ${ }^{1}$, José Uriel SEPÚLVEDA-VALENCIA ${ }^{1}$, \\ Eduardo RODRÍGUEZ-SANDOVAL ${ }^{1 *}$
}

\begin{abstract}
The effect of sweet whey and octenyl succinic anhydride (OSA)-modified cassava starch on the quality and rheological properties of fermented dairy beverages was evaluated. Sweet whey (45-65\%) and OSA-modified cassava starch (0.8-1.2\%) were added to determine an optimal fermented dairy beverage with the highest viscosity and the lowest syneresis possible. The optimal fermented dairy beverage corresponded to the addition of $40.9 \%$ sweet whey and $1.13 \%$ OSA-modified cassava starch with respect to the milk and sweet whey mixture. Moreover, the rheological and quality properties of the optimal fermented dairy beverage were compared to a commercial beverage (control) during 22 days of storage. No significant differences were found in soluble solids, acidity, $\mathrm{pH}$ and consistency index during the time evaluated, while the syneresis of both products showed an increase during storage. OSA-modified cassava starch can be used as a stabiliser in sweet whey fermented dairy beverages because it helps improve its quality properties.
\end{abstract}

Keywords: fermented dairy beverage; whey; modified cassava starch; rheology.

Practical Application: Modified cassava starch in fermented dairy beverage with whey is suitable in storage.

\section{Introduction}

Whey is a by-product of the cheese industry that is produced by separating the liquid part from the curd. It represents between $80 \%$ and $90 \%$ of the total volume of processed milk and contains about $50 \%$ of the nutrients in milk (soluble proteins, lactose, vitamins and minerals), making it a product with high nutritional and functional values. The nutritional composition of whey may vary considerably depending on the characteristics of the milk, the processing technology used in cheese production and the type of cheese produced. There are two basic types of whey: Sweet whey, from the production of cheeses by the proteolytic action of coagulating enzymes on milk casein micelles, and acid whey, obtained through fermentation process or the addition of organic acids or mineral acids to coagulate casein (Parra-Huertas, 2009; Poveda, 2013).

This by-product is usually considered a waste because of the lack of knowledge about its properties and difficult access to the technology needed for its processing and management (Hernández-Rojas \& Vélez-Ruiz, 2014; Poveda, 2013). This causes contamination problems in rivers and soils when discarded as effluent, as it affects the physical and chemical structure of the soil, and decreases the yield of agricultural crops or aquatic fauna due to its high biological oxygen demand (BOD) (Poveda, 2013).

However, in recent years, alternatives have been explored for its use, in order to take advantage of its different nutrients and its functional potential, as well as to reduce the pollution that its final disposal generates (Aider et al., 2009; Hernández-Rojas \& Vélez-Ruiz, 2014; Koutinas et al., 2009; Parra-Huertas, 2009). In some countries, it has been used in the elaboration of food products and supplements or as raw material to produce other ingredients and compounds (Hernández-Rojas \& Vélez-Ruiz, 2014; Poveda, 2013).

In the dairy industry, whey is used for the production of different products such as dairy beverages, cheeses and ice creams, taking advantage of their nutritional value, sensorial and functional properties, which improve texture, enhance flavour and colour, emulsify, stabilise and improve the flow properties (Akal \& Yetişemiyen, 2016; Parra-Huertas, 2009). In dairy beverages, the main benefits are its nutritional value and rehydration capacity. Moreover, whey can be added to achieve the required solids content, either as a protein concentrate or as a partial substitute for milk (Miranda-Miranda et al., 2014; Morell et al., 2015; Parra-Huertas, 2009). A milk beverage is described as an acidic protein liquid system with a stability and viscosity similar to yoghurt (Castro et al., 2013; Gomes et al., 2013).

The use of whey in dairy beverages can sometimes lead to more aqueous products, with an unpleasant mouthfeel when compared to other dairy beverages (Legarová \& Kouřimská, 2010). Generally, to achieve the desired viscosity and stability characteristics, emulsifiers and stabilisers are used to avoid the precipitation of proteins at their isoelectric point, preventing whey 
separation and improving the texture and sensory properties of the beverage (Paraskevopoulou et al., 2003; Wu et al., 2014).

Modified starches can be used as stabilisers or emulsifiers, which can modify or stabilise the texture or act as functional substitutes for milk fat (Abbas et al., 2010; Lobato-Calleros et al., 2014; Morell et al., 2015). Additionally, these starches may have a benefit on the health of the consumer due to their resistance to digestion in the small intestine and can improve some physicochemical properties of the product such as viscosity, gel formation and water retention capacity (decreasing syneresis) (Legarová \& Kouřimská, 2010; Lobato-Calleros et al., 2014; Morell et al., 2015). During storage, dairy beverages may present syneresis or changes in appearance and texture, which may affect the sensory perception of the consumer, causing them to be rejected (Amaya-Llano et al., 2008; Gomes et al., 2013). The use of starches can reduce syneresis and increase firmness during storage; but sensory defects like foreign flavours may also occur (Amaya-Llano et al., 2008).

Emulsions play very important roles in the formulation of foods, but they are thermodynamically unstable and are susceptible to destabilization. Emulsifiers, surface-active compounds, can adsorb at oil-water interface and facilitate emulsion formation. Octenyl succinic anhydride modified starch (OSA-starch) has been widely investigate for its good emulsifying property, which is mainly due to the introduction of hydrophobic alkenyl and hydrophilic carboxyl moiety at the same time in the relatively hydrophilic structure of starch molecule, meaning that it acquires amphiphilic nature and, thus, surface-active properties (Dapčević et al., 2014; Li et al., 2013). The OSA-starch has been used successfully in the areas of emulsions such as beverage, microencapsulation and thermoplastics and has an advantage compared with other emulsifiers such as gum arabic, casein, and gelatin, due to its low-cost and easy procurement (Sweedman et al., 2013; Timgren et al., 2013). In addition, cassava is an economically important crop in tropical regions and the research of its application as a modified cassava starch is an effort to develop the local starch modification industry in Colombia.

Taking into account the above and in order to take advantage of the whey resulting from cheese preparation, the effect of an octenyl succinic anhydride (OSA)-modified cassava starch on the rheological and quality properties of different formulations of a fermented dairy beverage with sweet whey was evaluated. Also, the fermented dairy beverage with the highest apparent viscosity and the lowest syneresis was chosen to compare its quality and rheological properties during storage versus a commercial fermented dairy beverage.

\section{Materials and methods}

\subsection{Materials}

The raw materials used in the experiment were bovine milk from the Paysandú Agrarian Station of the Universidad Nacional de Colombia-Sede Medellín, located in the district of Santa Helena (Medellín - Antioquia), calcium chloride (10043-52-4, Tecnas SA, Medellin, Antioquia), rennet (Maxiren ${ }^{\circledR}$ DSM, Sincle, France), lactase (Lactasa Proq 5300, Proquiga Group, Spain), octenyl succinic anhydride (OSA)-modified cassava starch
(Gel ${ }^{\circledR}$ Lact, Poltec SAS., La Estrella, Antioquia), sodium citrate (68-04-2, Tecnas SA, Medellín, Antioquia) and lactic acid bacteria (LAB) as functional starter culture for direct inoculation of milk, consisting of Streptococcus thermophilus, Lactobacillus bulgaricus and Lactobacillus lactis strains (ChoozitTM MY 800 LYO 5 DCU, Danisco France SAS, Epernon, France).

Sweet whey was obtained from the process of making white "Campesino" type cheese. The milk was standardised at $2.8 \%$ fat $\left(45^{\circ} \mathrm{C}\right.$ ) and pasteurised at $63^{\circ} \mathrm{C}$ for $30 \mathrm{~min}$. At $46^{\circ} \mathrm{C}, 10 \mathrm{~g}$ of calcium chloride were added and $1.2 \mathrm{~g}$ of rennet at $37^{\circ} \mathrm{C}$ were added to coagulate for $30 \mathrm{~min}$. After this time, the curd was divided with vertical and horizontal cheese lyres and strained. The resulting whey was subjected to a thermalisation process $\left(63^{\circ} \mathrm{C}\right)$ and stored under refrigeration.

The composition and physicochemical properties of sweet whey were $0.08 \%$ acidity (expressed as lactic acid), 6.5 of $\mathrm{pH}$, $7 \%$ total solids, $0.05 \%$ fat, $0.8 \%$ protein and $0.5 \%$ ash contents (Association of Official Analytical Chemists, 1997; Sepulveda Valencia et al., 2002)

\subsection{Preparation of fermented milk beverages}

Preliminary tests were performed on fermented dairy beverages, and the following inclusions were established: $45-65 \%$ sweet whey complementing with whole milk to $100 \%$ in the mixture and $0.8-1.2 \%$ of OSA-modified cassava starch based on the mixture of sweet whey and whole milk. Sodium citrate $(0.2 \%)$ and sugar (5.5\%) were also added to all samples, based on the same mixture. Milk and whey (40 kg) were mixed with $12 \mathrm{~mL}$ of lactase and this mixture was shaken and incubated for $20 \mathrm{~h}$ at $4{ }^{\circ} \mathrm{C}$. After the hydrolysis time, the mixture was heated to $45^{\circ} \mathrm{C}$ and the solid ingredients were added through constant stirring. The mixture was then homogenised at $1500 \mathrm{psi}$, pasteurised at $85^{\circ} \mathrm{C}$ for $5 \mathrm{~min}$, cooled to $42^{\circ} \mathrm{C}$, inoculated and incubated at the same temperature to achieve a titratable acidity of $0.52 \%$, expressed as a lactic acid percentage. Upon reaching the desired acidity, the mixture was refrigerated at $4{ }^{\circ} \mathrm{C}$ for $16 \mathrm{~h}$, beaten and the samples were extracted for analysis.

\subsection{Titratable acidity, $\mathrm{pH}$ and soluble solids}

After the beverages were refrigerated, they were stirred and the titratable acidity, $\mathrm{pH}$ and soluble solids were measured. The acidity was determined by the 947.05 method and expressed as a percentage of lactic acid equivalent (Association of Official Analytical Chemists, 1997). A mechanical refractometer with a scale from 0 to $32^{\circ} \mathrm{Brix}$ was used for the measurement of soluble solids (PCE-032. PCE-Instruments. Spain). The $\mathrm{pH}$ was measured at $5{ }^{\circ} \mathrm{C}$ using a Starter 3100 potentiometer (OAHUS, USA) by immersing the electrode in the dairy beverage sample. Each measurement was done in triplicate.

\subsection{Apparent viscosity}

The apparent viscosity was determined by the method implemented by Gauche et al. (2009) with some modifications. The samples were all kept at room temperature for $1 \mathrm{~h}$ after their preparation before the rheological test. A Brookfield DV-III 
ULTRA Programmable rheometer (Brookfield Engineering Laboratories, Stoughton, MA.) was used, equipped with a water bath, thermostatically controlled at $5^{\circ} \mathrm{C}$, and a concentric cylinder No. SC4-21. In order to measure the apparent viscosity, the equipment was programmed in the shear rate function that was increased linearly from $7.24 \mathrm{~s}^{-1}$ to $65.10 \mathrm{~s}^{-1}$. The viscosity value (cP) was taken at the shear rate of $50.64 \mathrm{~s}^{-1}$. The measurements were performed in triplicate.

\subsection{Syneresis}

The percent syneresis was determined six times for each sample. The dairy beverage $(20 \mathrm{~g})$ was centrifuged at $173 \mathrm{~g}$ for $10 \mathrm{~min}$ at $4{ }^{\circ} \mathrm{C}$. The supernatant was weighed and the syneresis was calculated in $\mathrm{g} / 100 \mathrm{~g}$ (Amaya-Llano et al., 2008).

\subsection{Comparison of dairy beverages}

The fermented dairy beverage with whey and OSA-modified cassava starch that presented the lowest syneresis and the highest viscosity (optimal) was selected to compare its characteristics with respect to a commercial fermented dairy beverage, used as beverage control (Auralac SA, Rionegro, Antioquia). The characteristics evaluated were titratable acidity, $\mathrm{pH}$, soluble solids, water activity (aw), moisture and fat content, and rheological properties. Acidity, $\mathrm{pH}$ and soluble solids were determined by the methods previously described. The water activity was measured on a dew point hygrometer (AquaLab Series 3TE, Decagon Devices Inc. Pullman, Washington, USA) (Bejarano-Toro et al., 2016). The moisture content was determined using a moisture balance (XM-60, Precisa Instruments AG, Switzerland) at $105^{\circ} \mathrm{C}$ until constant weight (Bertolino et al., 2015).

Fat content was determined by the modified Babcock method. The sample (9g) was weighed and placed in a butyrometer with $30 \mathrm{~mL}$ of the reagent (equal parts of perchloric acid $(72 \% \mathrm{v} / \mathrm{v})$ and glacial acetic acid $(95 \% \mathrm{v} / \mathrm{v}))$. The reagent and the sample were agitated and incubated in a water bath $\left(80^{\circ} \mathrm{C} / 5 \mathrm{~min}\right)$ and reagent was added up to the neck of the butyrometer and centrifuged ( $5 \mathrm{~min}$ ). The addition of reagent up to the neck of the butyrometer was repeated twice, centrifuging for $2 \mathrm{~min}$ and $1 \mathrm{~min}$, respectively. The mixture of sample and reagent was allowed to stand for $20 \mathrm{~min}$ and the amount of fat was measured (Bejarano-Toro et al., 2016). The fat percentage was calculated using Equation (1).

Fat $\%=\frac{1.5 * 0.068}{\text { sampleweight }} * 100$

The rheological properties, flow index (n) and the consistency index (k), were obtained from the power law, using the same equipment and the same conditions mentioned in the apparent viscosity test (Gauche et al., 2009).

\subsection{Behaviour during storage}

The behaviour during storage of the control beverage and the optimal dairy beverage with whey and OSA-modified cassava starch was evaluated. For this purpose, 3 milk samples were packed in $250 \mathrm{~mL}$ PET bottles for the following storage days: $0,3,7,11,15,18$ and 22 days, with a total of 21 samples per beverage. Syneresis, $\mathrm{pH}$, soluble solids, titratable acidity and rheological properties, flow index (n) and consistency index (k) were measured. Measurements were performed at least in triplicate.

\subsection{Experimental design and statistical analysis}

A response surface methodology (RSM) was used with 8 central points and 10 degrees of freedom. The inclusion level of sweet whey (45-65\%) and OSA-modified cassava starch (0.8-1.2\%) were considered as independent variables and acidity, $\mathrm{pH}$, soluble solids, apparent viscosity and percentage of syneresis as dependent variables or response. The design yielded 16 trials. Statgraphics Centurion XVI software Version16.1.02 was used. (Stat Point, Inc., USA). A completely randomised factorial design was used to verify the behaviour during the storage of fermented dairy beverages, taking as factors the type of beverage (control fermented dairy beverage and the optimal dairy beverage containing sweet whey and OSA-modified cassava starch) and the storage time. Data were analysed using the SAS statistical package, applying student's $t$ test when significant differences were found in the analysed variables.

\section{Results and discussion}

\subsection{Fermented dairy beverages with sweet whey and modified cassava starch}

The results obtained for acidity, $\mathrm{pH}$ and soluble solids of each treatment can be observed in Table 1. Both the inclusion of sweet whey and OSA-modified cassava starch were statistically significant $(\mathrm{p}<0.05)$ for apparent viscosity and syneresis, whereas the acidity, $\mathrm{pH}$ and soluble solids were not significantly affected by the addition of these ingredients. Figure 1 shows the response surface for the apparent viscosity of fermented dairy beverages with sweet whey and OSA-modified cassava starch, while Figure 2 shows the syneresis response surface for the same samples.

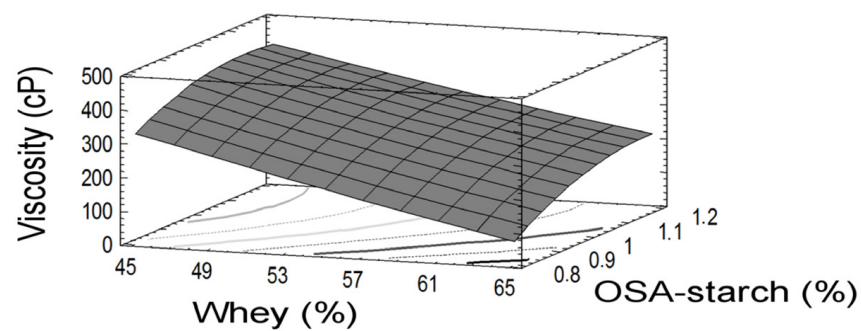

Figure 1. Response surface for the apparent viscosity of fermented dairy beverages with sweet whey and OSA-modified cassava starch.

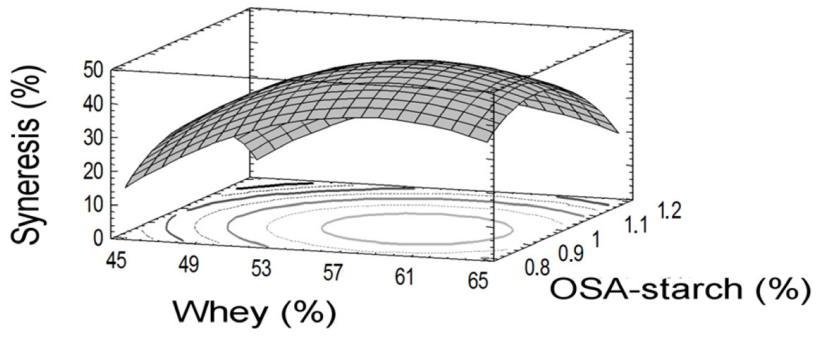

Figure 2. Response surface for the syneresis of fermented dairy beverages with sweet whey and OSA-modified cassava starch. 
Table 1. Quality properties of fermented dairy beverages with sweet whey and OSA-modified cassava starch using RSM.

\begin{tabular}{|c|c|c|c|c|c|c|c|}
\hline \multirow[b]{2}{*}{ Treatment } & \multicolumn{2}{|c|}{ Variables } & \multicolumn{5}{|c|}{ Response } \\
\hline & Sweet whey (\%) & $\begin{array}{c}\text { OSA- modified } \\
\text { cassava starch } \\
(\%)\end{array}$ & $\begin{array}{c}\text { Acidity } \\
\text { (\% lactic acid) }\end{array}$ & $\mathrm{pH}$ & $\begin{array}{l}\text { Soluble Solids } \\
\quad\left({ }^{\circ} \text { Brix }\right)\end{array}$ & $\begin{array}{c}\text { Apparent } \\
\text { viscosity }(\mathrm{cp})^{*}\end{array}$ & Syneresis (\%) \\
\hline 1 & 55.00 & 1.00 & $0.69 \pm 0.0$ & $4.06 \pm 0.0$ & $12 \pm 0.0$ & $302.11 \pm 27.9$ & $10.6 \pm 0.47$ \\
\hline 2 & 55.00 & 0.72 & $0.69 \pm 0.0$ & $4.03 \pm 0.0$ & $11.8 \pm 0.0$ & $139.94 \pm 5.0$ & $26.3 \pm 4.1$ \\
\hline 3 & 55.00 & 1.00 & $0.69 \pm 0.0$ & $4.09 \pm 0.0$ & $12 \pm 0.0$ & $249.04 \pm 12.1$ & $15.9 \pm 0.26$ \\
\hline 4 & 65.00 & 0.80 & $0.67 \pm 0.0$ & $4.02 \pm 0.0$ & $12 \pm 0.0$ & $95.73 \pm 1.4$ & $26.9 \pm 0.33$ \\
\hline 5 & 45.00 & 1.20 & $0.72 \pm 0.0$ & $3.90 \pm 0.0$ & $12 \pm 0.0$ & $389.80 \pm 8.5$ & $9.0 \pm 0.36$ \\
\hline 6 & 55.00 & 1.00 & $0.64 \pm 0.0$ & $3.98 \pm 0.0$ & $12 \pm 0.0$ & $235.54 \pm 11.1$ & $6.4 \pm 0.47$ \\
\hline 7 & 69.14 & 1.00 & $0.63 \pm 0.0$ & $4.01 \pm 0.0$ & $12 \pm 0.0$ & $96.88 \pm 10.2$ & $43.6 \pm 0.82$ \\
\hline 8 & 45.00 & 0.80 & $0.7 \pm 0.0$ & $3.98 \pm 0.0$ & $12 \pm 0.0$ & $285.58 \pm 11.3$ & $20.5 \pm 0.34$ \\
\hline 9 & 55.00 & 1.28 & $0.62 \pm 0.0$ & $4.01 \pm 0.0$ & $12 \pm 0.0$ & $292.92 \pm 11.5$ & $13.5 \pm 1.10$ \\
\hline 10 & 55.00 & 1.00 & $0.69 \pm 0.0$ & $3.98 \pm 0.0$ & $12 \pm 0.0$ & $273.87 \pm 5.1$ & $11.8 \pm 0.41$ \\
\hline 11 & 55.00 & 1.00 & $0.65 \pm 0.0$ & $4.19 \pm 0.0$ & $11.8 \pm 0.0$ & $241.50 \pm 14.4$ & $6.1 \pm 0.65$ \\
\hline 12 & 55.00 & 1.00 & $0.62 \pm 0.0$ & $4.08 \pm 0.0$ & $12 \pm 0.0$ & $397.84 \pm 21.2$ & $14.0 \pm 1.05$ \\
\hline 13 & 55.00 & 1.00 & $0.62 \pm 0.0$ & $4.07 \pm 0.0$ & $12 \pm 0.0$ & $336.45 \pm 15.2$ & $7.2 \pm 0.57$ \\
\hline 14 & 55.00 & 1.00 & $0.67 \pm 0.0$ & $4.11 \pm 0.0$ & $12 \pm 0.0$ & $299.20 \pm 21.5$ & $8.5 \pm 0.86$ \\
\hline 15 & 65.00 & 1.20 & $0.6 \pm 0.0$ & $4.11 \pm 0.0$ & $12 \pm 0.0$ & $253.99 \pm 15.4$ & $9.7 \pm 0.14$ \\
\hline 16 & 40.86 & 1.00 & $0.63 \pm 0.0$ & $4.29 \pm 0.0$ & $12 \pm 0.0$ & $519.44 \pm 18.8$ & $1.1 \pm 0.25$ \\
\hline
\end{tabular}

${ }^{\star}$ Evaluated at shear rate of $50.64 \mathrm{~s}^{-1}$.

Acidity in dairy beverages is related to the presence of solids, whether dairy-based or not, and the activity of LAB cultures and their ability to produce lactic acid from lactose (Castro et al., 2009). The acidity values were between 0.6 and $0.72 \% \mathrm{w} / \mathrm{v}$ of lactic acid, relatively lower than those reported in the literature (Castro et al., 2009; Gauche et al., 2009; Gomes et al., 2013). Gomes et al. (2013) reported $0.75 \%$ lactic acid in dairy beverages with $30 \%$ whey. Gauche et al. (2009) found values of 0.80 and $0.79 \%$ acidity for beverages with 20 and $30 \%$ of whey, respectively. Castro et al. (2009) reported acidities between 0.72 and $0.82 \%$ in dairy beverages made with different percentages of whey and oligofructose.

$\mathrm{pH}$ is considered as a control measure in the production of fermented dairy products. Changes in $\mathrm{pH}$ indicate $\mathrm{LAB}$ culture activity due to the production of lactic acid from lactose (Amaya-Llano et al., 2008). $\mathrm{pH}$ values found were between 3.9 and 4.29 , which were lower than those reported for fermented dairy beverages with $20 \%(4.36 \pm 0.01)$ and $30 \%$ whey $(4.34 \pm 0.01)$ (Gauche et al., 2009) and for non-fat yoghurts supplemented with $\beta$-glucans (4.36-4.48\%) (Sahan et al., 2008). Whereas for yoghurts supplemented with oligofructose as prebiotic ingredient, $\mathrm{pH}$ values of 4.1 were obtained (Cruz et al., 2013). Sugar content is a sensory quality index in dairy beverages, generally measured as a percentage of soluble solids ( ${ }^{\circ} \mathrm{Brix}$ ) (He et al., 2007; Shao \& $\mathrm{He}, 2009)$. The dairy beverages had $12 \%$ soluble solids ( $12^{\circ} \mathrm{Brix}$ ). Other authors have reported soluble solids of $16^{\circ} \mathrm{Brix}$ and between 18 to $20^{\circ} \mathrm{Brix}$ for low-fat yoghurts with inulin or polydextrose, respectively, and between 10.5 to $13.8{ }^{\circ}$ Brix in commercial yoghurts (He et al., 2007; Srisuvor et al., 2013).

Increasing the inclusion of sweet whey in the fermented dairy beverage decreased the apparent viscosity (Figure 1). A decrease in apparent viscosity and gel strength has been reported by including 20 and $30 \%$ of liquid whey in the yoghurt formulation (Castro et al., 2013; Gauche et al., 2009). The use of whey in the formulation of dairy beverages can be improved with the addition of other ingredients, such as transglutaminase, to obtain consistencies similar to yoghurt. The addition of transglutaminase to milk prior to the yoghurt fermentation step results in increased yoghurt gel strength. The intermolecular polymerization of caseins induced by transglutaminase improves the gelation, further the net pore size decreases resulting in more regular structural distribution, thus reducing syneresis (Gauche et al., 2009). The apparent viscosity is also affected by the total solids content in the formulation (Beitane \& Ciprovica, 2012). Increasing the amount of OSA-modified cassava starch in the fermented dairy beverage increased its apparent viscosity (Figure 1). Lobato-Calleros et al. (2014) reported an increase in apparent viscosity of yoghurts supplemented with modified corn and cassava starches compared to a control yoghurt, although the viscosity was lower when supplemented with native corn starch.

The viscosity of dairy beverages with $50 \%$ liquid whey in their formulation increased by increasing the corn starch concentration from 0.5 to $1 \%$ (Costa et al., 2013). It was also found that the viscosity of the yoghurt increased with higher concentrations of cross-linked acetylated cassava starch, which may be due to a reduction in the interactions between the casein micelles due to the presence of hydrophilic substituents or the interaction between casein and the modified starch (electrostatic coupling) (Cui et al., 2014). Morell et al. (2015) reported higher viscosity in yoghurts supplemented with physically modified starch than their non-starch counterparts, indicating that the starch granules act as a filling, reinforcing the protein network. However, not all modified starches improve the rheological properties of dairy beverages. No differences were found in the viscosity of yoghurt supplemented with corn and jicama starches modified by acid hydrolysis with $\mathrm{HCl}$, compared to their respective native starches as controls (Amaya-Llano et al., 2008). 
The viscosity of colloidal solutions depended upon dispersion medium and particle properties containing geometric shape, size, dispersibility and solvation. The effect of maltose on the stability and rheological properties of orange beverage (oil-in-water) emulsions formed by OSA-starch was evaluated. Part of maltose increased the viscosity due to the additional maltose-water and maltose-maltose hydrogen bond. The rest of maltose, interacted with OSA-starch adsorbed at the oil-droplet interface, resulted in the wrapped layer of oil droplets being closely packed and the effective volume of the particles increasing (Li et al., 2013). Therefore, the emulsion had higher viscosity because the oil droplets obtained more energy dissipation associated with fluid flow. Timgren et al. (2013) evaluated the emulsifying capacity and storage stability of OSA-starches from different resources and found that the resulting drop size decreased as the OSA-starch concentration increased, and the amount of starch attached to the surface of the drops increased resulting in a more stable emulsion. The volume fraction of the emulsion phase also increased as the concentration of the starch granules was increased. Another effect of the high OSA-starch concentration was that the amount of starch granules in the water phase of the emulsion and at the drop interface increased. This resulted in an increase of the total density of the drops and the emulsion phase. The behaviour described previously may be related to the fermented dairy beverage studied due to its composition such as casein, fat and moisture content.

Furthermore, the viscosity of dairy beverages or yoghurts may be increased by incorporating solids such as inulin, lactulose, polydextrose and $\beta$-glucans, among others (Beitane \& Ciprovica, 2012; Sahan et al., 2008; Srisuvor et al., 2013). Increasing the solids content may be a strategy to increase the viscosity and stability of the dairy beverages, but this practice can also develop certain defects such as increased acidity, excessive firmness, granular texture or increased syneresis (Gauche et al., 2009).

Syneresis refers to the presence of liquid on the surface of the gel, which forms during the fermentation due to its shrinkage and results in whey loss (Gauche et al., 2009; Sahan et al., 2008). This phenomenon can be caused by a change in the formulation of dairy beverages with low solids content, protein denaturation, a decrease in $\mathrm{pH}$, high acidity, high incubation temperatures or inadequate storage temperature, among others, and is considered a defect in this type of products (Amaya-Llano et al., 2008; Crispín-Isidro et al., 2015; Dal Bello et al., 2015; Castro et al., 2009; Sah et al., 2016).

Dairy beverages with higher sweet whey percentage had higher syneresis percentages (Figure 2), which may be caused by the formation of acidic gels and the higher intramicellar repulsion as a result of the increase in the positive charge of casein at lower $\mathrm{pH}$, below the isoelectric point of caseins. This could swell the casein particles, resulting in an increased rigidity of the milk gel (Penna et al., 2006). Likewise, it may be associated with an increase in the rigidity and stability of the protein network, since if the three-dimensional protein network is stronger, it loses its capacity to hold the whey, expels it from the matrix and is then observed on the surface of the fermented beverages (Castro et al., 2009; Gomes et al., 2013). Similar results were reported for dairy beverages as the amount of whey in their formulation was increased (Castro et al., 2009; Gauche et al., 2009). Syneresis may also be caused by other factors such as protein denaturation, low $\mathrm{pH}$, high acidity and thermic treatment conditions (Gomes et al., 2013). The syneresis percentages were lower than those reported by other studies with the exception of treatment 7, which had the highest amount of sweet whey $(69.14 \%)$ with syneresis close to $43.6 \%$ as shown in Table 1 (Gauche et al., 2009; Gomes et al., 2013).

In order to reduce syneresis in dairy beverages, stabilisers may be used, including different types of starches, with or without modification (Amaya-Llano et al., 2008; Zuo et al., 2008). According to the results, the syneresis percentage decreased as the amount of OSA-modified cassava starch increased (Figure 2). This behaviour was also evidenced in dairy beverages made with milk and whey (50:50) by increasing the concentration of corn starch (Costa et al., 2013). Similarly, the addition of cross-linked cassava and corn starches decreased the percentage of syneresis in reduced-fat yoghurts (Lobato-Calleros et al., 2014). Nevertheless, other studies have reported higher syneresis percentages in low-fat yoghurts with the addition of corn starch modified by acid hydrolysis when compared to a control yoghurt without the addition of starch. This effect was attributed to the ability of the modified corn starch to produce firm gels, prompted to retrogradation and water release, increasing the syneresis index (Amaya-Llano et al., 2008).

Applying the desirability function method, 16 solutions were obtained for the optimal criterion, which consisted of producing a fermented dairy beverage with higher apparent viscosity and lower syneresis. Desirability values were in the range of 0.6 to 0.9 (Results not shown). Under these criteria, optimum conditions with a desirability value of 0.9 were for a sweet whey inclusion of $40.9 \%$, corresponding to an addition of $59.1 \%$ of whole milk, and incorporating $1.13 \%$ of OSA-modified cassava starch with respect to the mixture of sweet whey and milk.

\subsection{Quality characteristics of dairy beverages}

Different quality characteristics of the optimal dairy beverage formulation with sweet whey (40.9\%) and OSA-modified cassava starch (1.13\%) were compared against the commercial beverage taken as control (Table 2). The control beverage presented higher values of soluble solids, fat and syneresis percentage, and lower moisture content and acidity. No significant differences were found for water activity. The beverages presented flow indexes

Table 2. Quality characteristics and rheological properties of the optimal fermented dairy beverage and control beverage.

\begin{tabular}{crr}
\hline Property & Control & Optimal \\
\hline Acidity (\% lactic acid) & $0.50 \pm 0.0$ & $0.72 \pm 0.0$ \\
pH & $4.23 \pm 0.0$ & $4.01 \pm 0.0$ \\
Soluble solids ( ${ }^{\circ}$ Brix) & $14.00 \pm 0.0$ & $12.00 \pm 0.0$ \\
Aw & $0.97 \pm 0.0$ & $0.97 \pm 0.0$ \\
Moisture content (\%) & $81.29 \pm 0.0$ & $83.78 \pm 0.0$ \\
Fat content (\%) & $1.12 \pm 0.0$ & $0.74 \pm 0.0$ \\
Syneresis (\%) & $2.34 \pm 0.1$ & $1.61 \pm 0.2$ \\
Flow index (n) & $0.44 \pm 0.0$ & $0.53 \pm 0.0$ \\
Consistency index (k, Pa.s) & $1.34 \pm 0.0$ & $2.36 \pm 0.0$ \\
\hline
\end{tabular}


of less than 1, indicating that they are pseudoplastic fluids. The optimal dairy beverage with sweet whey and OSA-modified cassava starch presented a higher consistency index. Fat in both beverages was lower than that reported by other authors for dairy beverages with whey in their formulation, with a value close to $2.03 \%$ (Gomes et al., 2013).

The acidity in both beverages was lower than that reported by other authors for dairy beverages with whey (Gomes et al., 2013). The final acidity depends on different factors such as the quantity and type of solids, the LAB culture activity and the fermentation period. Acidity values between 0.72 and $0.82 \%$ have been obtained for dairy beverages with whey (30-40\%) and oligofructose (2-5\%) during different fermentation periods (4.5-5.2 h) (Castro et al., 2009). Also, final acidity values for dairy beverages with different types of starches were higher than those of this study (>0.8\%) (Lobato-Calleros et al., 2014).

Milk casein micelles aggregate at their isoelectric point $(\mathrm{pH}=4.6)$ due to the collapse of $\kappa$-casein (Wu et al., 2014). The dairy beverages presented a $\mathrm{pH}$ below the isoelectric point of the caseins, allowing the aggregation of these proteins and yielding the texture and rheological characteristics of these products (Lee \& Lucey, 2004; Sah et al., 2016). The optimal dairy beverage with sweet whey and OSA-modified cassava starch presented the lowest $\mathrm{pH}$, which is related to its higher acidity. It could also be due to the slow cooling applied at the end of the fermentation period, since the microorganisms could have continued to act on the lactose for a longer period, producing greater amounts of lactic acid. The $\mathrm{pH}$ values found in the beverages were lower than those reported for low-fat yoghurts made with or without $\beta$-glucans, with a pH range of 4.43 to 4.48 (Sahan et al., 2008).

Both beverages presented lower percentages of syneresis than those reported in the literature for fermented dairy beverages and yoghurts (Castro et al., 2009; Gomes et al., 2013; Lobato-Calleros et al., 2014). As for the rheological properties, the beverages presented a pseudoplastic behaviour $(n<1)$, coinciding with the behaviour reported by other authors, who also found flow indexes of less than one for yoghurts and dairy beverages with whey (Cui et al., 2014; Lobato-Calleros et al., 2014; Morell et al., 2015; Sah et al., 2016).

The addition of modified starches reinforces the structure of dairy beverages through casein-starch interactions that contribute to the stabilisation of their structure (Cui et al., 2014; Morell et al., 2015; Sun et al., 2016). It is possible that the interaction between the OSA-modified cassava starch and the proteins was presented, and for this reason, the fermented dairy beverages showed a higher consistency index and therefore higher apparent viscosity than the control beverage. However, more rheological studies, such as verification of viscoelasticity, are required to confirm this assessment.

\subsection{Behaviour of the dairy beverages during storage}

The behaviour of acidity, $\mathrm{pH}$, soluble solids, syneresis and rheological properties during storage of the optimal fermented dairy beverage with sweet whey $(40.9 \%)$ and OSA-modified cassava starch $(1.13 \%)$ and control beverage are shown in Figure 3. Statistically significant differences $(\mathrm{p}<0.05)$ were found in the soluble solids content, acidity, $\mathrm{pH}$, flow indexes (n) and consistency $(\mathrm{k})$ between the dairy beverages evaluated, but these properties were not affected by the time in storage.

In other studies, the acidity increased and the $\mathrm{pH}$ decreased in fermented dairy beverages and yoghurts supplemented with modified corn and cassava starches, and fat-free or non-fat yoghurts during storage (Gomes et al., 2013; Lobato-Calleros et al., 2014; Sahan et al., 2008). Likewise, it was observed that the syneresis had no significant differences ( $p>0.05$ ) between beverages, but it was affected by the time in storage. The behaviour of syneresis observed in this study coincides with that reported for fermented dairy beverages and yoghurts with starch addition (Gomes et al., 2013; Lobato-Calleros et al., 2014). However, in non-fat yoghurts using $\beta$-glucan as fat replacer, a higher whey separation was obtained on the first day, whereas on subsequent days a decrease in this property was observed (Sahan et al., 2008).

As for the rheological properties, a similar behaviour was reported for the low-fat yoghurts supplemented with modified corn and cassava starches, which increased the stability during storage (Lobato-Calleros et al., 2014). In contrast, the apparent viscosity of yoghurts made with and without probiotics and prebiotics (inulin and pineapple peel powder) and low-fat yoghurts increased during storage (Sah et al., 2016; Sahan et al., 2008). The rheological properties of the dairy beverages could remain constant due to the presence of stabilisers in the case of the control beverage and due to the OSA-modified cassava starch in the case of the evaluated fermented dairy beverage. The starch granules can fill the proteins and, upon swelling, strengthen the protein network, allowing it to hold its structure (Morell et al., 2015).

The emulsion stabilization can be entirely electrostatic, entirely steric, or both (electrosteric stabilization). OSA starches can function as electrosteric stabilizers, but their function is primarily steric due to the size of the molecules relative to the number of charged groups. The steric stabilization is the mechanism whereby non-ionic water-soluble moieties stabilize because it is entropically unfavourable to compress these chains, as would occur if two sterically stabilized colloids were to come together (Sweedman et al., 2013). Furthermore, the interaction of modified starches and casein in a simulation yoghurt environment was studied and the results of zeta potential, fluorescence micrographs, FTIR and the morphological structure observed by SEM concluded that the main role of the interactions between OSA-starch and casein were the steric stabilization (Sun et al., 2016).

OSA starches are colourless and tasteless in solution and their capacities as stabilizers are essentially independent of $\mathrm{pH}$ and ionic strength of the medium because the steric stabilization is the dominant type in these starches. In fact, the oil-in-water emulsions had better stability against time using a commercial OSA starch rather than with whey protein isolate, although protein initially led to smaller particles immediately after homogenization (Sweedman et al., 2013). When starch was added to the gel, the density of the gel network structure was strong and the starch promoted to form the more continuous and compact network structures. The density of the gel network structure was stronger than other gels in the OSA-starch-casein gel. At low $\mathrm{pH}$, the number of the effective charge decreased and let the molecular 

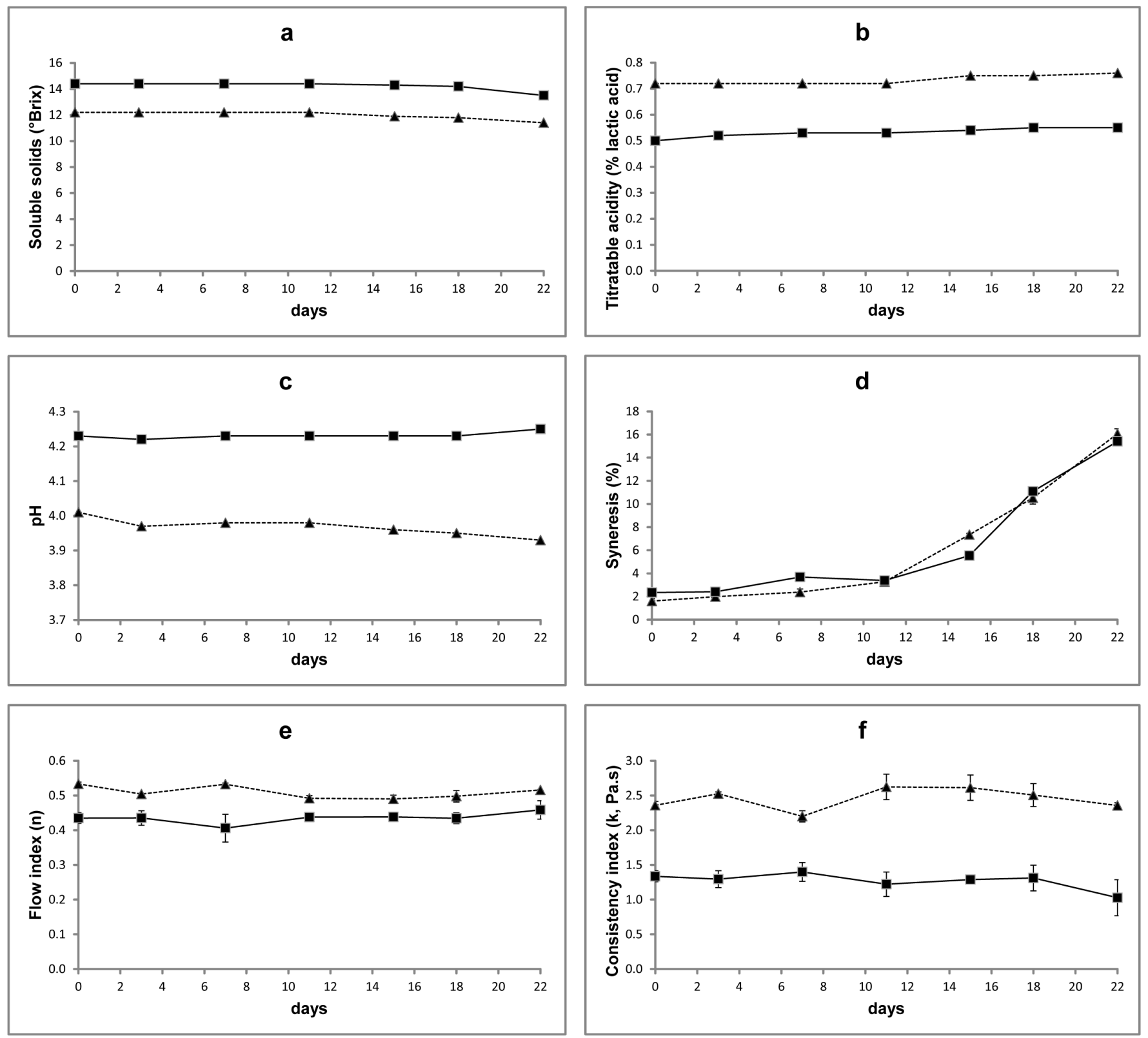

Figure 3. Behaviour of the quality and rheological properties of the optimal fermented dairy beverage (-- $\mathbf{\Delta}--)$ and control beverage (- during 22 days of storage: Soluble solids ( ${ }^{\circ}$ Brix) (a), titratable acidity (\% lactic acid) (b), pH (c), syneresis (\%) (d), flow index (n) (e), consistency index (k, Pa.s) (f).

chains curl easier due to reduced repulsive forces (Sun et al., 2016). It is important to note that the consistency index of the optimal dairy beverage was always higher throughout the storage time, meaning that the OSA starch gave suitable rheological properties to this product.

\section{Conclusions}

Increasing the inclusion of sweet whey in the formulation of the fermented dairy beverages decreases the apparent viscosity and increases syneresis, which are considered quality defects in this type of products. However, these effects decreased when OSA-modified cassava starch was used in the formulation. The optimal fermented dairy beverage, i.e. the one with the highest apparent viscosity and the lowest syneresis, corresponded to the sample that had a sweet whey addition of $40.9 \%$ and OSA-modified cassava starch of $1.13 \%$ with respect to the sweet whey and milk mixture.

The optimal fermented dairy beverage preserves its quality properties as soluble solids, acidity, $\mathrm{pH}$ and consistency index during the 22 days of storage. Moreover, the consistency index of the optimal fermented dairy beverage was always higher than that of the commercial beverage or control for the same storage time. The syneresis of both beverages increases during storage. The addition of OSA-modified cassava starch as a stabiliser in a fermented dairy beverage with sweet whey is suitable to keep its quality characteristics during storage. 


\section{Acknowledgements}

COLCIENCIAS is acknowledged for its financial support provided through contract 575 of 2013.

\section{References}

Abbas, K. A., Khalil, S. K., \& Hussin, A. S. M. (2010). Modified starches and their usages in selected food products: A review study. The Journal of Agricultural Science, 2(2), 90-100.

Aider, M., Halleux, D., \& Melnikova, I. (2009). Skim acidic milk whey cryoconcentration and assessment of its functional properties: Impact of processing conditions. Innovative Food Science \& Emerging Technologies, 10(3), 334-341. http://dx.doi.org/10.1016/j. ifset.2009.01.005.

Akal, C., \& Yetişemiyen, A. (2016). Use of whey powder and skim milk powder for the production of fermented cream. Food Science and Technology (Campinas), 36(4), 616-621. http://dx.doi. org/10.1590/1678-457x.06816.

Amaya-Llano, S. L., Martínez-Alegría, L., Zazueta-Morales, J. J., \& Martínez-Bustos, F. (2008). Acid thinned jicama and maize starches as fat substitute in stirred yogurt. Lebensmittel-Wissenschaft + Technologie, 41(7), 1274-1281. http://dx.doi.org/10.1016/j.lwt.2007.08.012.

Association of Official Analytical Chemists - AOAC (1997). Official Methods of Analysis. Gaithersburg: AOAC.

Beitane, I., \& Ciprovica, I. (2012). The study of synbiotic dairy products rheological properties during shelf-life. International Scholarly and Scientific Research \& Innovation, 6(7), 1889-1891.

Bejarano-Toro, E. E., Sepúlveda-Valencia, J. U., \& Restrepo-Molina, D. A. (2016). Characterization of a processed cheese spread produced from fresh cheese (quesito antioqueño). Revista Facultad Nacional de Agronomía, 69(2), 8015-8022.

Bertolino, M., Belviso, S., Dal Bello, B., Ghirardello, D., Giordano, M., Rolle, L., Gerbi, V., \& Zeppa, G. (2015). Influence of the addition of different hazelnut skins on the physicochemical, antioxidant, polyphenol and sensory properties of yogurt. Lebensmittel-Wissenschaft + Technologie, 63(2), 1145-1154. http://dx.doi.org/10.1016/j. lwt.2015.03.113.

Castro, F. P., Cunha, T. M., Ogliari, P. J., Teófilo, R. F., Ferreira, M. M. C., \& Prudêncio, E. S. (2009). Influence of different content of cheese whey and oligofructose on the properties of fermented lactic beverages: Study using response surface methodology. Lebensmittel-Wissenschaft + Technologie, 42(5), 993-997. http:// dx.doi.org/10.1016/j.lwt.2008.12.010.

Castro, W. F., Cruz, A. G., Bisinotto, M. S., Guerreiro, L. M. R., Faria, J. A. F., Bolini, H. M. A., Cunha, R. L., \& Deliza, R. (2013). Development of probiotic dairy beverages: Rheological properties and application of mathematical models in sensory evaluation. Journal of Dairy Science, 96(1), 16-25. PMid:23102956. http://dx.doi.org/10.3168/ jds.2012-5590.

Costa, A. V. S., Nicolau, E. S., Torres, M. C. L., Fernandes, P. R., Rosa, S. I. R., \& Nascimento, R. C. (2013). Desenvolvimento e caracterização físico-química, microbiológica e sensorial de bebida láctea fermentada elaborada com diferentes estabilizantes/espessantes. Semina: Ciências Agrárias, 34(1), 209-226. http://dx.doi.org/10.5433/16790359.2013v34n1p209.

Crispín-Isidro, G., Lobato-Calleros, C., Espinosa-Andrews, H., AlvarezRamirez, J., \& Vernon-Carter, E. J. (2015). Effect of inulin and agave fructans addition on the rheological, microstructural and sensory properties of reduced-fat stirred yogurt. Lebensmittel-Wissenschaft + Technologie, 62(1), 438-444. http://dx.doi.org/10.1016/j.lwt.2014.06.042.
Cruz, A. G., Cavalcanti, R. N., Guerreiro, L. M. R., Sant'Ana, A. S., Nogueira, L. C., Oliveira, C. A. F., Deliza, R., Cunha, R. L., Faria, J. A. F., \& Bolini, H. M. A. (2013). Developing a prebiotic yogurt: Rheological, physico-chemical and microbiological aspects and adequacy of survival analysis methodology. Journal of Food Engineering, 114(3), 323-330. http://dx.doi.org/10.1016/j.jfoodeng.2012.08.018.

Cui, B., Lu, Y. M., Tan, C. P., Wang, G. Q., \& Li, G. H. (2014). Effect of cross-linked acetylated starch content on the structure and stability of set yoghurt. Food Hydrocolloids, 35, 576-582. http://dx.doi. org/10.1016/j.foodhyd.2013.07.018.

Dal Bello, B., Torri, L., Piochi, M., \& Zeppa, G. (2015). Healthy yogurt fortified with n-3 fatty acids from vegetable sources. Journal of Dairy Science, 98(12), 8375-8385. PMid:26409962. http://dx.doi. org/10.3168/jds.2015-9688.

Dapčević, T. R. H., Dokić, L. P., Hadnađev, M. S., Pojić, M. M., \& Torbica, A. M. (2014). Rheological and breadmaking properties of wheat flours supplemented with octenyl succinic anhydride-modified waxy maize starches. Food and Bioprocess Technology, 7(1), 235-247. http://dx.doi.org/10.1007/s11947-013-1083-y.

Gauche, C., Tomazi, T., Barreto, P. L. M., Ogliari, P. J., \& Bordignon-Luiz, M. T. (2009). Physical properties of yoghurt manufactured with milk whey and transglutaminase. Lebensmittel-Wissenschaft + Technologie, 42(1), 239-243. http://dx.doi.org/10.1016/j.lwt.2008.05.023.

Gomes, J. J. L., Duarte, A. M., Batista, A. S. M., de Figueiredo, R. M. F., de Sousa, E. P., de Souza, E. L., \& Queiroga, R. C. R. E. (2013). Physicochemical and sensory properties of fermented dairy beverages made with goat's milk, cow's milk and a mixture of the two milks. Lebensmittel-Wissenschaft + Technologie, 54(1), 18-24. http://dx.doi. org/10.1016/j.lwt.2013.04.022.

He, Y., Wu, D., Feng, S., \& Li, X. (2007). Fast measurement of sugar content of yogurt using Vis/NIR-spectroscopy. International Journal of Food Properties, 10(1), 1-7. http://dx.doi.org/10.1080/10942910600575658.

Hernández-Rojas, F. M., \& Vélez-Ruiz, J. F. (2014). Suero de leche y su aplicación en la elaboración de alimentos funcionales. Temas Selectos de Ingeniería de Alimentos, 8(2), 13-22.

Koutinas, A. A., Papapostolou, H., Dimitrellou, D., Kopsahelis, N., Katechaki, E., Bekatorou, A., \& Bosnea, L. A. (2009). Whey valorisation: A complete and novel technology development for dairy industry starter culture production. Bioresource Technology, 100(15), 3734-3739. PMid:19254836. http://dx.doi.org/10.1016/j. biortech.2009.01.058.

Lee, W. J., \& Lucey, J. A. (2004). Structure and physical properties of yogurt gels: Effect of inoculation rate and incubation temperature. Journal of Dairy Science, 87(10), 3153-3164. PMid:15377593. http:// dx.doi.org/10.3168/jds.S0022-0302(04)73450-5.

Legarová, V., \& Kouřimská, L. (2010). Sensory quality evaluation of whey-based beverages. Mljekarstvo, 60(4), 280-287.

Li, C., Fu, X., Luo, F., \& Huang, Q. (2013). Effects of maltose on stability and rheological properties of orange oil-in-water emulsion formed by OSA modified starch. Food Hydrocolloids, 32(1), 79-86. http:// dx.doi.org/10.1016/j.foodhyd.2012.12.004.

Lobato-Calleros, C., Ramírez-Santiago, C., Vernon-Carter, E. J., \& Alvarez-Ramirez, J. (2014). Impact of native and chemically modified starches addition as fat replacers in the viscoelasticity of reduced-fat stirred yogurt. Journal of Food Engineering, 131, 110-115. http:// dx.doi.org/10.1016/j.jfoodeng.2014.01.019.

Miranda-Miranda, O., Fonseca, P. L., Ponce, I., Cedeño, C., Rivero, L. S., \& Vázquez, L. M. (2014). Elaboración de una bebida fermentada a partir del suero de leche que incorpora Lactobacillus acidophilus y Streptococcus thermophilus. Revista Cubana de Alimentación y Nutrición, 24(1), 7-16. 
Morell, P., Hernando, I., Llorca, E., \& Fiszman, S. (2015). Yogurts with an increased protein content and physically modified starch: Rheological, structural, oral digestion and sensory properties related to enhanced satiating capacity. Food Research International, 70, 6473. http://dx.doi.org/10.1016/j.foodres.2015.01.024.

Paraskevopoulou, A., Athanasiadis, I., Blekas, G., Koutinas, A. A., Kanellaki, M., \& Kiosseoglou, V. (2003). Influence of polysaccharide addition on stability of a cheese whey kefir-milk mixture. Food Hydrocolloids, 17(5), 615-620. http://dx.doi.org/10.1016/S0268005X(02)00122-4.

Parra-Huertas, R. A. (2009). Lactosuero: importancia en la industria de alimentos. Revista Facultad Nacional de Agronomía, Medellín, 62(1), 4967-4982.

Penna, A. L. B., Gurram, S., \& Barbosa-Cánovas, G. V. (2006). Effect of high hydrostatic pressure processing on rheological and textural properties of probiotic low-fat yogurt fermented by different starter cultures. Journal of Food Process Engineering, 29(5), 447-461. http:// dx.doi.org/10.1111/j.1745-4530.2006.00076.x.

Poveda, E. (2013). Suero lácteo, generalidades y potencial uso como fuente de calcio de alta biodisponibilidad. Revista Chilena de Nutricion, 40(4), 397-403. http://dx.doi.org/10.4067/S0717-75182013000400011.

Sah, B. N. P., Vasiljevic, T., McKechnie, S., \& Donkor, O. N. (2016). Physicochemical, textural and rheological properties of probiotic yogurt fortified with fibre-rich pineapple peel powder during refrigerated storage. Lebensmittel-Wissenschaft + Technologie, 65, 978-986. http://dx.doi.org/10.1016/j.lwt.2015.09.027.

Sahan, N., Yasar, K., \& Hayaloglu, A. A. (2008). Physical, chemical and flavour quality of non-fat yogurt as affected by a $\beta$-glucan hydrocolloidal composite during storage. Food Hydrocolloids, 22(7), 1291-1297. http://dx.doi.org/10.1016/j.foodhyd.2007.06.010.

Sepulveda Valencia, J. U., Florez Florez, L. E., \& Pena Alvarez, C. M. (2002). Use of lactoserum of fresh cheese in the elaboration of a fermented beverage with addition of maracuya pulp (Passiflora edulis) purple variety and carboxyl methyl cellulose (CMC), enriched with vitamins A and D. Revista Facultad Nacional de Agronomia, 55(2), 1633-1674.

Shao, Y., \& He, Y. (2009). Measurement of soluble solids content and ph of yogurt using visible/near infrared spectroscopy and chemometrics. Food and Bioprocess Technology, 2(2), 229-233. http:// dx.doi.org/10.1007/s11947-008-0180-9.

Srisuvor, N., Chinprahast, N., Prakitchaiwattana, C., \& Subhimaros, S. (2013). Effects of inulin and polydextrose on physicochemical and sensory properties of low-fat set yoghurt with probiotic-cultured banana purée. Lebensmittel-Wissenschaft + Technologie, 51(1), 3036. http://dx.doi.org/10.1016/j.lwt.2012.10.018.

Sun, N. X., Liang, Y., Yu, B., Tan, C. P., \& Cui, B. (2016). Interaction of starch and casein. Food Hydrocolloids, 60, 572-579. http://dx.doi. org/10.1016/j.foodhyd.2016.04.029.

Sweedman, M. C., Tizzotti, M. J., Schäfer, C., \& Gilbert, R. G. (2013). Structure and physicochemical properties of octenyl succinic anhydride modified starches: A review. Carbohydrate Polymers, 92(1), 905-920. PMid:23218383. http://dx.doi.org/10.1016/j.carbpol.2012.09.040.

Timgren, A., Rayner, M., Dejmek, P., Marku, D., \& Sjöö, M. (2013). Emulsion stabilizing capacity of intact starch granules modified by heat treatment or octenyl succinic anhydride. Food Science \& Nutrition, 1(2), 157-171. PMid:24804025. http://dx.doi.org/10.1002/fsn3.17.

Wu, J., Du, B., Li, J., \& Zhang, H. (2014). Influence of homogenisation and the degradation of stabilizer on the stability of acidified milk drinks stabilized by carboxymethylcellulose. Lebensmittel-Wissenschaft + Technologie, 56(2), 370-376. http://dx.doi.org/10.1016/j.lwt.2013.12.029.

Zuo, J. Y., Hemar, Y., Hewitt, S., \& Saunders, A. (2008). Effect of the extent of pasting on the dynamic rheological properties of acidified skim milk gels containing normal rice starch. Food Hydrocolloids, 22(8), 1567-1573. http://dx.doi.org/10.1016/j.foodhyd.2007.10.009. 